\title{
存量土地活化的机制与主体研究 基于台湾社区营造经验的延伸探讨
}

Mechanism and Subjects of Reinvigorating the Stock Land: Based on the Community Empowerment Experience of Taiwan

摘要: 城市居住型存量土地的价值有着极大的提升空间。存量规划与社区营造二元互 补, 共同活化城市存量土地。现阶段大陆居民参与有待提高, 需要借鉴社区营造机制, 通过社会氛围活化带动地域空间发展。社区营造的机制是以项目为抓手，以社区精神 为纽带, 实现多元推动主体的参与和互动, 共同促进社区发展。本文归纳出的五个推 动主体包括领导团队、居民、社区规划师、政府与非政府组织, 它们的相互关系与作 用决定着社区营造的走向甚至成败。台湾地区的成功经验在于社区营造理念及相应的 运作机制，而大陆地区在政府组织架构及执行力、历史文化积淀、居民集体意识等方 面具有优势。新常态下的存量土地活化, 应该重视多元主体参与、乡愁氛围的营造以 及制度创新设计。

Abstract: The value of urban residential stock land has great potential to be increased. It is binary complementary of stock planning and community empowerment to reinvigorating the stock land. Citizens of mainland China should be encouraged to take part in community development. Among the multiple approaches, the one which activates the social atmosphere could develop the regional space. The mechanism of community empowerment focuses on the following aspects: operated by projects; linked by community spirit; multiple subjects participated and interacted, hence the development of community could be promoted. The relationship and interactions among five participate subjects include group leaders, citizens, community planners, public sector, and non-government organizations will affect whether the community empowerment could achieve success. The successful experience of Taiwan provides the idea and mechanism of community empowerment; while mainland China has advantages of governmental structure, power of execution, accumulation of history and culture, collective consciousness of citizen, etc. In order to reinvigorate the stock land, the research emphasizes participation of multiple subjects, cultivated nostalgia, and institutional innovation in the new normal.

关键词：社区营造；存量土地；台湾经验；机制；主体

Keywords: Community Empowerment; Stock Land; Taiwan Experience; Mechanism; Subject

厦门大学田野调查基金（2015GF024）
当前城市规划导向逐渐从增量规划向存量 规划转变, 由新城建设向旧城再开发转变。存 量土地更新不同于增量土地开发。继续沿用粗 放式的增量土地开发模式, 忽视存量土地再利 用, 将加剧城市空间异化、公共资源分配失衡。 大面积迁出居民、重新规划业态、甚至大拆大 建等传统粗放模式是不可持续的。由此, 政府 提出了控制城市无序蔓延、“遵循严控增量、盘 活存量、优化结构、提高效率的总要求” 1 回顾近十年来学界对存量土地与旧城发展问题 的研究, 主要聚焦于城市存量土地空间、制度、 经济、产业等 ${ }^{[1-15]}$ 方面 $^{(2)}$ 。对于人的主体性在 旧城发展中的重要作用, 到目前为止尚未有过 系统的认知与论述。忽略主体的作用, 单纯强 调空间、业态的改善, 必然陷人城市灵魂缺位 的困境。

社区营造本质上是一套多元主体参与的良性 协调机制。然而, 台湾地区的社区营造研究强调 个性化的影响因素, 以个案为对象, 缺少运行机 制的提炼, 或者不够全面。大陆方面相应的研究 也缺乏整体机制层面 ${ }^{[16-18]}$, 特别是对营造主体的

作者: 杨哲, 厦门大学建筑与土木工程学院副教授。decoart@sina.com 初松峰, 厦门大学建筑与土木工程学院硕士。chusongfeng@foxmail.com

(1) 国土资源部《关于推进土地节约集约利用的指导意见》(2014)，参见中华人民共和国国土资源部网站 http://www.mlr.gov.cn/zwgk/zytz/201409/ t20140926 1331065.htm。

(2) 近十年来对存量土地的研究, 主要包括从权属制度入手 ${ }^{[1-3]}$, 采取制度设计与政策支持 ${ }^{[4]}$, 盘活存量土地 ${ }^{[5]}$, 科学评价存量土地 ${ }^{[6]}$, 创新城市更 新项目技术指标 ${ }^{[7]}$, 探索老城区历史发展演替机制 ${ }^{[8]}$, 分析其用地转化 ${ }^{[9]}$ 及更新机制 ${ }^{[10]}$ 。针对存量土地中具有较高文化价值的历史街区, 从类 型学 ${ }^{[11]}$ 、空间肌理 ${ }^{[12]}$ 等方面激发城市活力 ${ }^{[13]}$; 同时, 商业开发能拉动历史街区存量土地价值, 带动经济发展 ${ }^{[14,15]}$ 。 
把握不够全面 ${ }^{1}$ 。本文旨在摆脱个别案例叙事的方式, 以深人 台湾部分社区调查以及亲身参与其间所获的第一手资料为依 据, 结合行政机构的相关文件, 分析社区营造主体的作用与运 行机制, 并结合两岸经济、社会发展现状, 分析制度环境与参 与主体特征差别, 提出通过社会氛围活化、体制机制创新、引 领主体参与, 来带动存量地域空间的更新发展。

\section{1 概念解析}

存量议题作为近几年我国规划转型的重要方向, 受到学 界高度关注。以城市存量空间为对象, 可以采用自上而下（存 量规划) 与自下而上（社区营造）互补结合的方式, 实现活 化的目标。

\section{1 存量规划}

台湾地区 1998 年颁布实施的《都市更新条例》第四条 规定：采取 “重建、整建、维护”三种方式, 改善更新地区 内的建筑质量与公共设施 ${ }^{2}$ 。大陆的城市更新模式与之类似, 并于近年来发展成通过城市更新等手段促进建成区功能优化 调整的存量规划, 包括旧城改造更新、环境综合治理、土地 整备与拆迁安置等方面 ${ }^{[19]}$ 。存量规划是对增量规划的反思与 改良 ${ }^{[20]}$, 作为一种专业手段, 其空间布局由 “形态构建” 转 向 “结构调整” ${ }^{[21]}$, 是尊重产权基础上对规划内容的变更, 同时需要空间规划与制度设计相结合 ${ }^{[22]}$ 。

虽然两岸的土地所有权性质、公共参与方式等方面有很 大不同, 但是在存量规划 (都市更新 ${ }^{3}$ ) 的导向上都体现出 政府主导的改造思路（表 1)。直观表现在：以经济发展与 空间结构优化作为更新的首要目标; 垂直的政策执行序列; 对公众参与途径的规定局限于意见征询、公开展示等方式

\section{表 1 两岸存量土地发展制度比较}

\begin{tabular}{|c|c|c|}
\hline 地区 & 大㮫 & 台湾 \\
\hline $\begin{array}{l}\text { 土地 } \\
\text { 所有权 }\end{array}$ & $\begin{array}{l}\text { 《土地管理法》第 } 8 \text { 条: } \\
\text { 城市市区的土地属于国家 } \\
\text { 所有。 }\end{array}$ & $\begin{array}{l}\text { 《土地法》第 } 10 \text { 条: 经人民依法取得 } \\
\text { 所有权者, 为私有土地。私有土地之 } \\
\text { 所有权消灭者, 为国有土地。 }\end{array}$ \\
\hline $\begin{array}{l}\text { 专项法律 } \\
\text { 法规 }\end{array}$ & $\begin{array}{l}\text { 《城乡规划法》《城市规划 } \\
\text { 编制办法》《国有土地上 } \\
\text { 房屋征收与补偿条例》 }\end{array}$ & $\begin{array}{l}\text { 《都市更新条例》《区段征收实施办 } \\
\text { 法》《市地重划实施办法》 }\end{array}$ \\
\hline 执行方式 & 拆迁安置补偿 & 区段征收、市地重划等手段 \\
\hline
\end{tabular}

资料来源 : 大陆法令整理自全国人大网 http://www.npc.gov.cn/, 台湾部分整理自 “我的 $\mathrm{E}$ 政府”网 http://www.gov.tw/
(表 2)。因此, 居民实质上是被动的参与者, 积极性与参与 效果均会受到不同程度的抑制。

\section{2 社区营造}

社区营造起源于居民自主意识觉醒, 是自下而上的改善 机制。应对存量土地问题时, 通过各方多维度参与, 留住原 有居民，形成积极的社会氛围，提升社区的商业价值、环境 价值与社会价值。二十多年来, 台湾地区通过 “社区总体营 造” 理念 ${ }^{[23]}$, 提升了民众的参与度, 改善了居住条件, 从理 念到实践形成了一系列行之有效的工作方式。

\section{3 存量土地活化}

“活态” 是存量土地发展的目标, 是指在城市空间中保 持着缤纷多彩的生活方式和不断创新的社会环境。建设是短 期的, 本地居民生活是长期的。历史积淀的习惯、风俗、文 化塑造出城市的特殊品格, 铸就特别的场所精神, 是一种无 形的文化价值。完全迁走原有居民, 推倒历史场所, 无异于 将城市变作一具空壳子, 再炫目的商业中心也会由于缺乏本 土文化而显得突匹。成功的存量活化都是在政府指导下, 依 靠本地居民参与, 结合社会力量, 保持城市经济活力, 传承 历史文化的精髓, 维系城市品格。在当前“新常态” 经济发 展环境下, 更应摆脱重物质轻精神的土地经营态度与范式, 依托中国人数千年来视土地为家园的观念, 激发居民对故土 的怀念与挚爱, 勾起最深刻的乡愁情结。

\section{4 存量规划与社区营造二元互补}

资本流动的压力引起社会解体与重构。大拆大建模式着

\section{表 2 两岸存量土地发展公众参与制度比较}

\begin{tabular}{c|l|l|l}
\hline 地区 & 法令名称 & 条款 & \multicolumn{1}{c}{ 规定要点 } \\
\hline 大陆 & 城乡规划法 & 第 26 条 & 组织编制机关应当充分考虑专家和公众的意见 \\
\cline { 2 - 4 } & $\begin{array}{l}\text { 城市规划 } \\
\text { 编制办法 }\end{array}$ & 第 5 条 & $\begin{array}{l}\text { 充分关注中低收人人群, 扶助弱势群体, 维护 } \\
\text { 社会稳定和公共安全 }\end{array}$ \\
\hline 台湾 & $\begin{array}{l}\text { 都市更新 } \\
\text { 条例 }\end{array}$ & 第 10 条 & 划定更新单元时举办公听会 \\
\cline { 2 - 4 } & 第 19 条 & $\begin{array}{l}\text { 拟定或变更都市更新计划期间, 应举办公听会, } \\
\text { 听取民众意见 ; 送审前公开展览 } 30 \text { 日 }\end{array}$ \\
\cline { 2 - 4 } & $\begin{array}{l}\text { 区段征收 } \\
\text { 实施办法 }\end{array}$ & 第 2 条 & 准备阶段与实施阶段均需召开 “公听会” \\
\hline
\end{tabular}

资料来源：大陆法令整理自中国政府网 http://www.gov.cn/, 台湾部分整理自“内政部营建 署” 网 http://www.cpami.gov.tw/

\footnotetext{
(1) 大陆学者对社区营造的研究主要有: 研究城市规划的社区指向趋势, 并从规划的“工具理性”到“交往理性”演进解读社区规划师的制度和实践 $[16]$; 对台湾社区营造机制概括为公众参与和非政府组织参与 ${ }^{[17]}$; 针对台湾社区规划师制度的形成与发展进行探析 ${ }^{[18]}$ 。

(2) 参见台湾 “内政部营建署” 网站 http://www.cpami.gov.tw/。

(3) 台湾的《都市更新条例》和《都市更新权利变换实施办法》等文件对更新区域内的产权评估有明确规定。
} 
眼于短期经济利益, 引发社会与城市空间的剧烈变动, 加速 解体的过程, 后果往往是对历史、文化脉络的割裂。应对此 种问题, 由政府主导的精英式存量规划能够快速提出更多倾 向于技术手段的空间层面的改善方案，却容易低估居民与社 会的力量, 公众参与途径往往停留于象征性参与阶段 ${ }^{[24]}$ 。而 社区营造恰好可以在一定程度上弥补这种不足。它是对社会 与城市空间的弥合与重构, 缓解资本对城市社会构架的冲击, 在解体与重构之间获得多赢的平衡。因此, 可以将存量规划 与社区营造看作二元互补的存量土地发展机制。通过自上而 下的规划总体引导与自下而上的居民实践相结合, 既留住原 有居民、保留传统文化习俗, 又优化城市结构, 弥合快速发 展所忽略的空间裂痕, 维持城市活力。

\section{2 社区营造的机制：关键因素与步骤}

社区活力的恢复是城市发展动力机制的创新, 无法单独 在城市物质空间层面实现, 需要从仅仅关注建设活动, 转向 关注包括社会经济及居住形态在内的全部社会活动 ${ }^{[25]}$ 。具体 到城市社会生活单元, 社区营造机制着眼于社区内外互动的 全过程，包括社区营造项目、推动主体、社区精神三个方面 及其互动规律。

\section{1 社区营造机制中的关键因素}

社区营造是一个从自发组织逐步演变为成熟机制的过 程, 包含了社区营造项目、社区精神、推动主体三个关键要 素及其互动机制, 涵盖物质、精神与人三个层面。营造项目 是关键抓手，直接或间接地影响社区空间、居民生活。社区 精神作为维系居民关系的纽带, 为社区发展提供精神动力。 作为推动主体的人, 由于身份、职业与角色的差异, 区分为

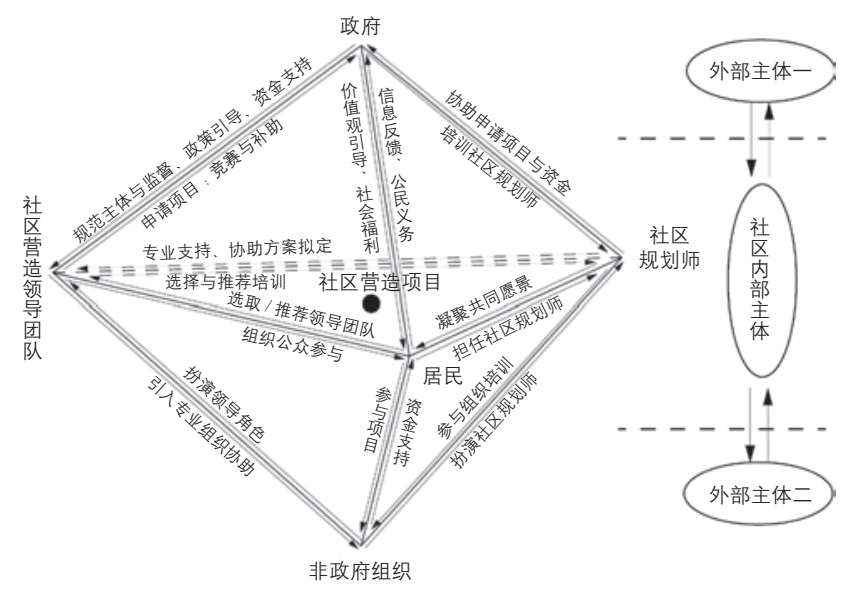

图 1 社区营造机制的模型 资料来源：作者绘制
政府 $^{1}$ 、社区营造领导团队、居民、社区规划师、非政府组织。 它们之间需要增加相互接触的机会, 尊重彼此利益, 达成共 同愿景（图 1)。没有主体的推动, 社区营造不会产生与发展; 没有项目的支撑, 社区营造将缺乏落脚点, 沦为空谈的口号, 无法改善现实生活环境; 没有社区精神, 居民将丧失凝聚力, 社区力量一盘散沙, 营造或沦为一场空热闹。

\subsection{1 社区营造项目}

多种社区营造项目源于社区自主开展、政府与非政府组 织的提供, 如产业导人、环境改造、低碳社区、志工服务、 社区运动会等 ${ }^{[26]}$ 。由于参与主体的不同, 可细分为社区层面 与居民层面（图 2)。表 3 列出了笔者所调研或参与的台湾 地区 14 个县市中 28 个社区营造案例, 不难发现 : 成功的社 区营造离不开两个层面项目的共同推动。

社区层面的营造项目具有宏观导向、投资大、关注度高 等特点, 如政府或非政府组织推动的低碳社区项目, 需要大 量外部政策与资金支持、社区内外协力才能共同完成。

与社区层面相比, 居民层面的营造项目在引导居民参与、 融洽社区内部关系方面具有不可替代的作用。它又可分为服 务性项目和活动性项目。前者由居民组建志愿者团体, 强调 服务社区及其他居民, 如“社区环境志工队” 和“社区老年 人服务队” 等。活动性项目则吸引居民走出家门, 接触社区, 为居民提供交流平台。例如, 宜兰县白米社区以皮雕课程为 先导, 培养热心居民担任木屐博物馆的解说员与 DIY 示范员。

\subsection{2 社区精神}

社区精神本质在于人对生活空间的归属感, 维系着居民 的内心情感和外在行为。这些情感凝练为浓厚的乡愁意蕴,

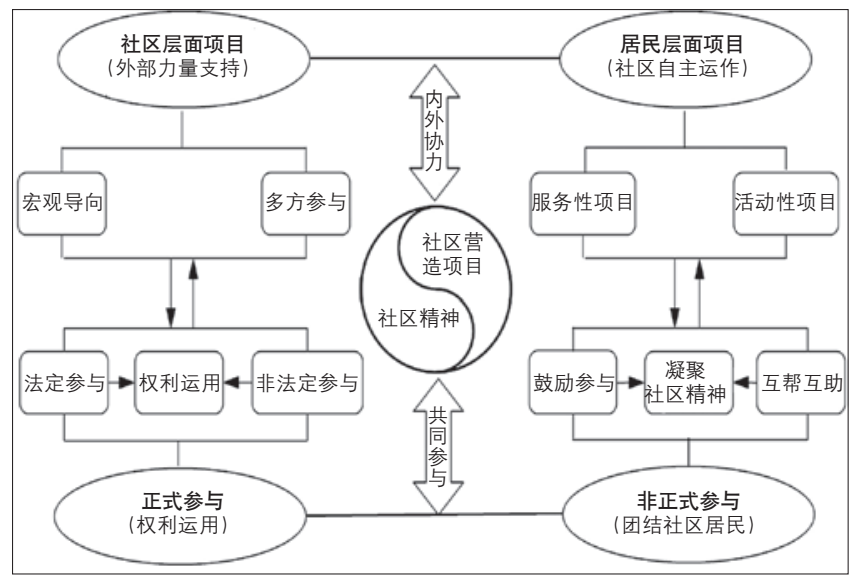

图 2 社区营造项目和居民公众参与的内在关系 资料来源：作者绘制

(1) 本文所说的 “政府”，广义上指代国家或地区的行政机关及其下属部门与立法机关等公共部门 (public sector)，不具有政治性意义（government）。 
表 3 台湾地区 28 个社区营造成功案例统计表

\begin{tabular}{|c|c|c|c|c|c|}
\hline 所处地域 & 里/乡/社区 & 社区层面项目（内外协力） & 居民层面项目（自主运作） & 领导团队 & 资料来源 \\
\hline 台北市 & 剑潭里 & 绿建筑改造、社区花园建设等 & 社区志工、周末讲座 & 里长团队 & 笔者调研 \\
\hline \multirow[t]{3}{*}{ 新北市 } & 顺德里 & $\begin{array}{l}\text { 雨扑满与绿能屋顶建设、“高速公路剩余 } \\
\text { 空间改造” 项目 }\end{array}$ & 志工服务、社区课程 & 里长团队 & 笔者调研 \\
\hline & 平潭社区 & “磺潭文化艺术村”项目 & “一人一树人人植树护水源” 活动等 & 社区发展协会 & 郭士杰 (2011) \\
\hline & 泰山乡 & 产业发展项目 & DIY 芭比娃娃的衣服等 & 社区合作社 & 黄郁胜 (2008) \\
\hline \multirow[t]{2}{*}{ 云林县 } & 港尾村 & 社区空间改造项目等 & “环境识别游戏” 等 & 七嵌文化促进会等 & 黄世辉 (2001) \\
\hline & 湖本村 & 反对陆沙开采项目 & 居民参与 · 共同设计湖本桥等 & 环保志工队 & 黄世辉 (2001) \\
\hline \multirow[t]{4}{*}{ 南投县 } & 埔里镇 & 主题观光发展项目 & 社区特色街道创意比赛等 & - & 黄世辉 (2001) \\
\hline & 涩水社区 & 有机农业发展项目 & 志工服务 & 社区发展协会 & 黄世辉 (2001) \\
\hline & 社寮里 & $\begin{array}{l}\text { 八通关古道观光开发项目、美化传统文 } \\
\text { 化建筑空间计划 }\end{array}$ & “画地图话邻里”等参与设计活动 & $\begin{array}{l}\text { 社寮文教基金会、紫南 } \\
\text { 宫管理委员会 }\end{array}$ & 黄世辉 (2001) \\
\hline & 梅林社区 & 糯米桥产业文化振兴系列项目 & 老人、外籍配偶照顾计划 & 社区发展协会 & 郑和 (2009) \\
\hline \multirow[t]{2}{*}{ 台南市 } & 关庙 & 竹藤产业发展项目 & 竹藤艺术品设计竞赛等 & - & 黄世辉 (2001) \\
\hline & 溪美社区 & “新大同社会社区照顾网”项目等 & 老年人健康服务、社区全民运动会 & 社区发展协会 & 王万此 (2006) \\
\hline 花莲县 & 牛犁社区 & 安全社区建设项目等 & 居民制作社区地图 & 社区交流协会 & 邱于珊 $(2010)$ \\
\hline \multirow[t]{3}{*}{ 嘉义县 } & 山美社区 & 原住民文化保护项目 & 邹族传统舞蹈团、传统手工艺班等 & 社区发展协会 & 吕嘉泓 (1999) \\
\hline & 刘厝里 & 新故乡社区营造一一社区风貌营造项目 & 居民清扫环境、参与规划会议 & 社区干部 & 扈凯晖 (2007) \\
\hline & 明华社区 & 环保及农业再生项目 & 湿地认养、河堤彩绘 & 社区发展协会 & 陈明扬 (2013) \\
\hline 屏东县 & 建功村 & 森林亲水公园项目 & 村民参与 “森林亲水公园项目” 建设施工等 & 社区发展协会 & $\begin{array}{l}\text { 吴志文 (2004) } \\
\text { 赖怡吟 (2006) }\end{array}$ \\
\hline \multirow[t]{2}{*}{ 桃园县 } & 东势庄 & 客家文化保存项目 & 客家用具 DIY 等 & 东势庄文化协会 & 周玉堡 (2011) \\
\hline & 大溪镇 & 街屋立面保存项目 & 历史街区讲解员培训等 & 社区发展协会 & 笔者调研 \\
\hline \multirow[t]{2}{*}{ 宜兰县 } & 白米社区 & 地方产业文化特色辅导项目 & 木履 DIY、皮雕班、小解说员 & 社区发展协会 & 笔者调研 \\
\hline & 鄂王社区 & 巷弄改造, 杨士芳纪念园项目 & 灯笼制作培训班 & 社区发展协会 & 笔者调研 \\
\hline \multirow[t]{4}{*}{ 新竹县 } & 北埔乡 & $\begin{array}{l}\text { 地方传统建筑空间美化项目, 街角博物 } \\
\text { 馆建设项目 }\end{array}$ & 改造项目公听会 & $\begin{array}{l}\text { 台湾大学建筑与城乡研 } \\
\text { 究发展基金会 }\end{array}$ & 笔者调研 \\
\hline & 新埔镇 & 宗祠博物馆建设项目 & “柿饼节”、口述老故事等 & 宗祠博物馆联营工作站 & 笔者参与 \\
\hline & 信势社区 & 北势溪环境整治项目 & 成立社区儿童才艺班、全体居民大扫除等 & $\begin{array}{l}\text { 社区发展协会, 社区管 } \\
\text { 理委员会 }\end{array}$ & 杨桂珍 (2008) \\
\hline & 内湖社区 & 社区空间改造项目 & 公听会、说明会、巡守队 & - & 邹萍萍 (2008) \\
\hline 金门县 & 新前墩聚落 & 六星社区示范项目、低碳社区项目等 & 志工服务、妈妈教室、乡村文化季 & 社区发展协会 & 张志伟 (2011) \\
\hline 台东县 & 永安社区 & 永安社区绿茵工程（共两期）等 & 社区守望队、社区解说员 & $\begin{array}{l}\text { 仙人掌乡土工作室, 社 } \\
\text { 区发展协会 }\end{array}$ & $\begin{array}{l}\text { 黄䞏雅 (2010) } \\
\text { 杨司焕 (2013) }\end{array}$ \\
\hline 台中市 & 龙兴里 & “五福临门” 周边环境改造系列项目等 & 环保义工、妈妈教室、社区守望 & 社区发展协会 & 刘建志 $(2010)$ \\
\hline
\end{tabular}

注：“一”表示没有数据

资料来源：作者根据现场调研及本文附录的文献综合整理

反作用于社区空间的改造。社区营造不单是塑造有形空间, 更是将物质的世界与无形的精神统合起来, 反馈于作为主体 的人。因此, 社区空间的意义不局限于其自身, 更重要的是 作为社区精神的物化体现, 把人凝聚起来。权力与资本博亦 条件下, 很多历史街区的改造花费不菲, 过度的商业化缺少 甚或破坏了原有历史文化积淀的精神, 核心价值反而淡化为 商业文化的幌子或陪衬。欧美城市复兴、城市更新、大规模 城市综合体等, 其发展历程充分证明了商业化必须承载公共
生活空间、社区精神导向的责任。当代中国文化环境处于既 要弥补传统断裂、又要与西方拉近差距的急切转型期, 乡愁 代表着历史文化的深厚底蕴, 其长远意义必须得到全社会的 深刻领悟。

归属感的培育, 既是社区营造的精神源泉，也是营造的 重要目标。空间与制度的改善, 固然可以调节个体、集体与 环境之间的关系, 然而让居民以主人公的姿态自觉参与社区 营造, 更能从根本上培养、传承社区精神。正是每个居民对 
自身生活环境的“微影响”, 聚合成整个社会永续发展的大 力量。

\section{2 社区营造机制的关键步骤}

社区营造并非政府设定剧本然后大家按部就班执行，而 是基于居民自有产权以非正式更新的方式，通过社区内部的 自主运作、外部力量的支持、内外协力发展三个关键步骤发 展壮大（图 1, 表 3)。

\subsection{1 社区自主运作}

社区领导团队、居民、规划师最为了解社区情况，能识 别社区中亟待改善的问题。通过自组织的方式开展居民层 面的营造项目, 协调各方关系, 促使社区人力与资源动起来。 随着营造项目成果的不断累加, 整体提升社区生活与文化 品质。

社区自主运作是营造的萌芽, 早期的参与人数可能较少 且形式不规范, 需要领导团队、居民、规划师的持续互动、 不断改进, 才能吸引更多居民参加。营造的效果也往往需要 经过一段时期的累积才能显现。

\subsection{2 外部力量支持}

政府与非政府组织是社区营造的外部推动主体, 提供 必不可少的支持。社区作为基层组织, 人员、财力与影响力 等资源都很有限, 容易捉襟见肘。而政府与非政府组织能调 配更多的人才与资源, 结合社区实际需求, 寻求适合的发展 途径与模式。新北市顺德里高速公路剩余空间改造项目 (一 期）动员社区居民动手将垃圾堆建设成生态步道（图 3 左）。 发展到第二期时, 得到 “国道高速公路管理局” 的资助, 环 境大幅度改善 (图 3 右)。

\subsection{3 社区内外协力的持续推动}

社区营造的成功一定是不同的推动主体内外协力的结 果。单一项目的深化与不同项目的接续启动, 将会逐次提升
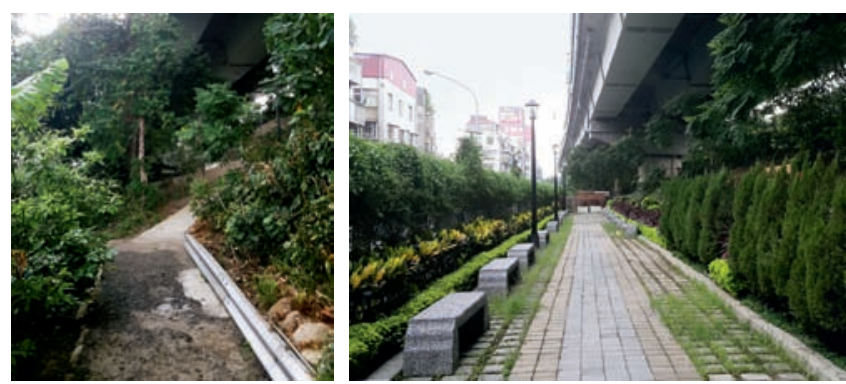

图 3 新北市顺德里高速公路剩余空间改造项目一期 (社区自建) 与 二期 (外界资助) 对比 资料来源 : 作者拍摄, 2014-8-4
社区环境。因此, 社区营造是需要持续推动的长期过程。一 旦内外主体不能协调, 导致项目无法继续, 或者项目之间存 在长时间的断裂, 那么, 存量土地将失去生机。新竹市金山 社区的居民与外来的规划师团队前期（1996-1998 年）相 互配合, 营造成果在台湾岛内影响很大。后来由于新建高铁、 工业园区, 传统邻里关系被瓦解, 居民内部难以形成凝聚力, 又没能够从政府或非政府组织争取到足够的资金与政策支 持, 最终社区营造也就停滞了 ${ }^{[27]}$ 。

\section{3 社区营造的主体}

资源使用的效率要点在于权利界定 ${ }^{281}$, 资源使用的权利、 收人的权利若没有清楚的界定, 就会产生较高的制度费用 ${ }^{[29]}$, 进而导致营造失败。云林县龙潭社区的里长、社区发展协会、 老人会之间权责部分重叠冲突, 加之物资管理、居民信任度 等方面的问题, 该社区的营造县花一现, 归于沉寂 ${ }^{[30]}$ 。本文 所概括的五个推动主体 (图 1) 因角色分化, 在社区营造机 制的运行中必须对各自的分工与职能加以清晰的界定, 才能 有助于社区内外协力、良性互动发展, 避免权责界定不清引 发的无效率消耗。

\section{1 政府}

存量土地的再利用, 除了直接规划开发, 改变土地功 能, 引导旧城更新等传统手段外, 还应构建居民自主更新机 制。作为社区营造的重要推动主体, 政府可以发挥的职能有: （1）清晰界定各方权责, 通过法律法规赋予社区营造组织 与个人的法律地位; (2) 顶层设计、宏观协调辖区的营造项 目; (3) 设定社区营造目标, 项目政策引导、资金支持、运 行监督、成果评估并择优推广, 不断给社区注人活力。以下 结合台湾经验从三方面来归纳政府角色定位与作用。

\section{1 .1 制度规范与引导}

台湾地区行政机关以专项计划的方式进行政策上的引 导, 支持社区规划师优化具体方案。1994年 “行政院文建会” 提出 “社区总体营造” 概念, 台湾社区营造开始走上多角度 切人的制度化进程 (表 4)。20多年来, 台湾地区的社区生 活环境与文化水平获得了整体的提升。

\section{1 .2 权责界定与人力支持}

社区营造领导团队、社区规划师、居民等主体的参与权 利与责任, 需要从法律法规的层面上加以清晰的界定。1991 年《社区发展工作纲要》赋予社区发展协会独立的法人地 位, 从制度上保障社区发展协会作为重要的组织力量。此外, 界定并培训社区规划师, 充实社区营造的专业力量。设立 


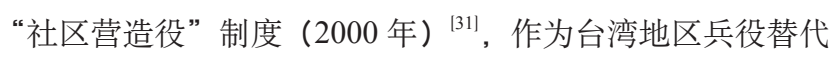
制度 ${ }^{1}$, 旨在协助“社区总体营造”政策, 培养年轻人服务 社区的意识, 担负起传承社区营造的责任 ${ }^{2}$ 。

\subsection{3 社区营造项目的重要来源}

台湾地区行政机构不同层级的部门通过发布营造项目, 以社区营造竞赛或补贴的方式进行资金支持。自《新故乡计 划》(2003 年) 开始, 改变原有平均发放补助的方式, 转为 辖区内各社区针对某一主题申请营造项目, 通过竞争获得营 造经费。这个计划 “鼓励创意、合作、行动、地方参与及价 值创新” 的理念和做法, 可以归结为 “竞赛一评选一奖励一 示范” 的政府推动体系。

另一方面, 作为竞赛奖励机制的补充, 经费补贴对竞争 力较弱的社区是必不可少的。台东县永安社区 2001-2009 年间分别从“文建会”、“内政部”、“水保会”、“农务局”等 6 个行政部门及基金会获得经费补助（约新台币 2171 万元）,

\section{表 4 近 20 年台湾地区行政机构关于社区发展的相关政策}

\begin{tabular}{|c|c|c|}
\hline 时间（年） & 主管单位 & 相关政策文件 \\
\hline 1991 & “社会司” & 社区发展工作纲要 \\
\hline 1994 & “文建会” & 社区总体营造 \\
\hline 1996 & “社会司” & 加强推展社区发展工作实施方案 \\
\hline 1998 & “社会司” & 加强老人安养服务方案 \\
\hline 1999 & “文建会” & 地方文化产业振兴计划 \\
\hline 1999 & “文建会” & 灾后重建计划工作纲领 \\
\hline 1999 & “卫生署” & 健康社区营造计划 \\
\hline 2001 & “文建会” & “九十年”社区总体营造 \\
\hline 2001 & “文建会” & $\begin{array}{l}\text { “行政院” 社区总体营造计划心点子创意 } \\
\text { 征选活动 }\end{array}$ \\
\hline 2001 & “营建署” & 创造台湾城乡风貌示范计划 \\
\hline 2002 & “文建会” & $\begin{array}{l}\text { “九十一年度” 社区总体营造委托专业工 } \\
\text { 作团队计划 }\end{array}$ \\
\hline 2003 & “文建会”、“营建署” & 新故乡社区营造计划 \\
\hline 2004 & “行政院” & 社区营造条例（草案） \\
\hline 2005 & “行政院” & 台湾健康社区六星计划 \\
\hline 2006 & “环保署” & 清净家园全民运动计划 \\
\hline 2010 & “环保署” & 低碳社区推动专案工作计划（第一年） \\
\hline
\end{tabular}

用于社区环境提升，其中包括 “永安社区绿茵工程” 和 “乡 村营造之人力培训计划” 等项目 ${ }^{[32]}$ 。

\section{2 社区营造领导团队}

群体活动须有自发或推举的引领人物。社区营造领导团 队是社区内部的直接组织者, 可以由上级任命, 也可以是居民 自发组成。无论是大陆的居委会, 还是台湾的里长团队、社 区发展协会、公寓大厦住户委员会等均属于这个范畴（表 3)。 从新制度经济学角度来看, 领导团队的存在, 是为了降低居民 参与的组织成本与社区发展的信息费用, 能够最为直接地推动 项目的运转, 沟通社区内外。其职责为：（1）作为组织者与管 理者, 代表居民向政府争取项目、政策与资金支持, 并组织实 施; (2) 带动居民重新了解、认识自己的社区, 规划发展蓝图, 凝聚社区共识；（3）通过政府机构推广、新闻媒体报道、网络 平台交流等方式进行宣传, 共享成功的营造经验。

\section{3 居民}

增量开发模式不可能适应产权结构复杂的旧城。如果按 现有很多城市的做法, 简单地搬迁原有居民, 损害的不仅是 融洽的社区情感, 更重要的是割裂了社区的历史文化及其精 神。居民是社区营造的直接参与者与目标受益者。居民参与 是活化存量土地的润滑剂, 能直面旧城房屋繁杂的公、私所 有权问题, 有效减少土地再利用的制度成本; 同时, 体现了 人在城市中的主体性地位, 并能使社区人力资源利用最大化。

居民的公众参与可以是正式或非正式两种形式（图 2)。 正式参与针对社区层面的营造项目, 需要居民表达意见、使 用权利、多方协商。例如, 在社区规划前召开居民大会, 保 障居民知情权; 规划图纸完成后召开公听会, 对规划进行修 改完善, 保障居民参与权; 承担项目实施的具体工作, 直接 行使维护自身利益的权利 ${ }^{3}$ 。非正式参与的目的在于改善社 区软环境, 实现社区内部团结, 对应居民服务性项目与居民 活动性项目 ${ }^{4}$ 。

\section{4 社区规划师}

社区规划师扮演引导公众参与、筹划地域空间活化方案 的专业角色, 同样属于标签性概念, 包括 “外来的”与 “在地

(1) 兵役替代制度（简称为 “替代役”）是指将需要服兵役但超出军队接纳能力的超额人员，分配至各公共部门服务，以替代兵役的一种制度。参 见台湾地区“内政部役政署”网站 http://www.nca.gov.tw。

(2) 参见台湾地区“文化部” 网站 http://www.moc.gov.tw/main.do?method=find\&checkIn=1。

(3) 日常工作中, 台北市剑潭里以“邻长工作汇报”的形式, 总结社区营造中公众参与的情况; 新北市顺德里在“绿能屋顶项目”运作前, 召开住户会议、 听取意见，并且成立居民维护小组，管理项目。

(4) 南投县梅林社区的“老人、外籍配偶照顾计划”、台南市溪美社区的老年人健康服务等, 都针对社区老龄化问题, 志愿者提供健康服务, 鼓励 老人走出家庭。 
的”。所谓 “在地”, 就是当地居民通过专业培训, 学习相关政 策、掌握一定的规划专业技术，成为 “社区中的规划师”，引 导社区发展潮流, 落实 “永续社区” 和“低碳社区”等理念 ${ }^{[33]}$, 并结合社区实际状况，灵活运用规划工具加以改造。由于他们 长期生活在社区之中，对社区历史、居民关系、现存问题非常 熟悉，因此在社区规划中更具优势。社区规划师的职责是协助 领导团队向政府申请社区营造项目，争取政策或资金 ; 共同拟 定社区营造方案，在项目实施过程中提供专业技术支持 ${ }^{1}$ 。

\section{5 非政府组织}

不属于行政体系的行业协会、工作坊、基金会、公司 等非政府组织 ( $\mathrm{NGO}$ ), 直接领导或间接推动社区营造, 起 着重要的支撑作用。例如, 新竹县新埔宗祠博物馆联营工作 站实际上扮演了领导团队的角色。该组织计划用 7 年（笔者 2015 年开始参加时已经进行到第 4 年）恢复和修缮 10 座宗 祠, 唤醒居民的族群观念, 吸引游客, 带动地方经济。笔者 亲身参与了这个工作坊, 与来自海峡两岸、日本、马来西亚 的专家以及本地居民一起勘访现场, 从店铺改造到街巷空间, 从基础设施到历史文化, 进行多角度、高效率的探讨与设计。 这样做的结果是, 以宗祠文化为核心, 新埔镇空间与经济的 每一步发展都是所有人共同期待并亲自决定的。

\section{4 “新常态”下的存量土地活化机制}

“新常态”下的城乡规划势必要求改变过去快速扩张、 粗放发展的模式, 关注重点由增量规划转向存量规划。以上 海为代表的一线城市提出, 到 2020 年实现规划建设用地总 规模零增长, 探索以土地利用方式的转变来倒逼经济增长方 式的转型升级 ${ }^{2}$ 。近几年中国各地城乡发展也越来越呈现这 种城市土地从数量扩张转向质量提升的趋势。从社区营造机 制的多元主体关系，不难发现，若能发挥好中国大陆自身诸 多优势, 界定好各推动主体的责权、设计好不断创新的体制 机制, 那么存量土地的活化将获得更高的效率和质量。以下 通过两岸经济社会差异条件下机制与主体的对比分析, 导出 “新常态” 存量激活机制中各方主体的权责利及在此基础上 的制度设计。“活力设计”和“奖补并重”则是激发主体意 识的创新途径与手段。

\section{1 两岸的经济社会差异}

存量土地活化其实就是对现有资源的再次分配, 涉及居 民、政府、企业等多方面的利益。长期以来, 两岸的经济、
社会与制度差异造成主体不同的行为与选择, 下文对比 “行 政机关、社会、市民三大主体” (3) 的分异, 分析大陆的优劣势, 进而奠定新制度设计的基础。

\subsection{1 经济下行阶段的政府职能转变}

存量活化是经济下行压力倒逼的城市发展方向调整。从 世界范围来看, 我国大陆依然保持着较高速的经济增长; 但 是纵向比较, 经济下行已十分明显 (表 5)。为了应对这种 趋势性的转变, 需要对城市内部低效利用的土地进行再开发, 激活土地价值。台湾经济曾经快速发展, 跻身“亚洲四小 龙”, 后来增速逐渐放缓, “十大建设”后的基础设施更新节 奏放缓, 在民粹的影响下行政机关决策门槛提高, 难以快速 应对新的情况变化。国民党与民进党轮替执政, 随意废止之 前的决定，导致大量建设资金浪费（如台北市远雄公司 “大 巨蛋” 案), 经济困难更是雪上加霜。

较之于台湾地区行政机关, 大陆各级政府的组织力与执 行力更强, 在城乡发展中具有更重大的引导作用, 在规范或 划分各推动主体角色职责时更具话语权。这种强势姿态在过 去相当长的一段时间里有效地推动了城市的快速发展, 但是, 新的形势必然要求政府职能从强势开发向重点支持转变, 侧 重引导、评估其他主体的工作成效。这样的顶层设计, 可以 充分发挥大陆 “齐心办大事” 的特点, 构建有组织、有政策、 有资金、有人才、宣传得力的体制与机制（表 6)。

\subsection{2 “以和为贵”与 “社区抗争” 的居民参与流变}

权益抗争是台湾社区营造的重要起源。随着台湾 “解 严” 以来政治气氛逐渐和缓, 为了应对居民收人与破败的环 境之间的矛盾，在行政机关无力投人大笔资金全面提升空间 质量的情况下, 居民自我组织, 亲自动手改善环境, 争取自 身权益。以宜兰县白米社区为例, 前期居民时常向附近的水 泥厂提出抗议, 并逐渐团结起来, 为社区环境发声, 共同整 顿公共空间与绿化环境。1994 年, 白米社区接受社区营造 理念, 选择传统木屐产业为切人点, 逐步走向正规化, 最终 成功建设运营 “木履博物馆”。

\section{表 5 近 3 年来两岸国民生产总值增长率统计表}

\begin{tabular}{lccc}
\hline & $\mathbf{2 0 1 3}$ 年 & $\mathbf{2 0 1 4}$ 年 & 2015 年 \\
\hline 大陆地区 GDP 增长率 (\%) & 10.34 & 8.14 & 6.90 \\
台湾地区 GDP 增长率 (\%) & 2.20 & 3.92 & 0.75 \\
\hline
\end{tabular}

资料来源: 大陆数据来自国家统计局网站 http://www.stats.gov.cn/，台湾数据来自 “行政院” 网站 http://www.ey.gov.tw/

(1) 顺德里的居民经过“新北市社区规划师培训项目”, 与里长配合, 申请营造项目, 改造空间环境。该社区最终获得台湾地区“优秀低碳社区”的称号。

(2) 参见中央政府门户网站 http://www.gov.cn/xinwen/2014-04/25/content_2666424.htm。

(3) 参见 2015 年中央城市工作会议。 
大陆有许多大中型企事业单位, 占地面积大、区位条件 优, 但是基础设施日渐陈旧。居民们经过长期集体主义的熏 陶, 组织意识较强, 理应成为存量土地发展的主动参与者。 随着法律知识的普及, 居民的知情权、参与权等维权意识也 将有助于塑造法制化的参与机制。在这种集体意识与法律意 识的双重影响下, 社区居民更容易形成 “以和为贵” 的发展 理念。位于厦门市海沧区新阳街道的兴旺社区, 地处国家级 台商投资区, 二十余年来快速城镇化导致人口数量激增 5 倍, 社区居民大多是企业职工, 外来人口比重高达 $81 \%$ 。为了更 好地融人社区, 居民通过自组织成立合唱团、组建社工中心 等非正式参与途径, 凝聚社区情感, 社区自主运作取得成效。 2013 年 7 月被选为“美丽厦门, 共同缔造” 的两个试点区 域之一, 政府出台 “以奖代补” 政策实施办法, 企业、个人 投人数百万元资助建设综合服务中心, 成立基金会等。最终 通过社区内外协力的持续推动, 建成社区组织孵化基地、社 区图书馆、社区大学 ${ }^{[34]}$ 等设施, 并且通过居民自发成立 “故 事小屋”, 引导外来居民子女的亲子活动, 保持社区长效和 谐的发展 ${ }^{[35]}$ 。

\subsection{3 社会部门: 存量活化的专业力量}

习近平总书记在城市工作会议上明确指出, 社会是城市 发展的主体之一。这其中包含了 $\mathrm{NGO}$ 与社区规划师等推动 主体。从社会部门的主体身份来看, 企业与商家是市场经济 的主要参与者, 拥有较为成熟的组织运作体系, 能够及时高 效地应对存量活化中的各种变化, 调整策略。行业协会、基 金会、社会团体等能够以特定的活化目标为中心, 以专业的 视角, 设置一系列的参与项目, 吸引各类人群参与。这些社 会部门更接地气, 直面百姓需求, 用专业手段深人探讨并采 取行动。与台湾相比, 大陆的社会部门发育尚不完善, 缺乏 法律法规清晰而明确地界定各类社会部门的权、责、利。在 工程实践中, 社会部门往往依赖政府发挥作用, 缺乏直接沟 通本地居民的途径, 也局限了社会部门在存量活化中的作用。
通过以上对比分析可看出, 应当充分发挥大陆政府与居 民的优势, 弥补社会部门的短板, 借鉴社区营造机制, 通过 制度设计鼓励居民参与, 活化城市存量土地。

\section{2 活力设计一一活化存量土地的总体设计}

城市活力的恢复并非单纯依靠物质空间形态, 而是经济、 文化、生态的协调发展, 体现为业态、形态、文态与生态的 综合繁荣 (图 4)。活力设计即是基于这种观念, 针对活力 下降的存量土地, 采用制度设计与空间改造相结合的方式, 激发新的城市活力 (表 7)。在形态上, 梳理城市肌理, 凸 显公共空间与历史建筑特色; 在生态上, 升级基础设施, 保护、 利用山水格局与地方资源要素; 在业态上, 摒弃机械规定业 态分区的生硬模式, 利用原有或植人“业态种子” 加以培育, 再以 “点一线一面” 逐次提升的方式, 将产业发展脉络有机 化; 在文态上, 历史与现代并置, 空间与精神交融, 让城市 底蕴、乡愁氛围得到具有时代特征的传承和延续。

厦门的曾厝垵近些年来特别火热。一开始它只是一座普

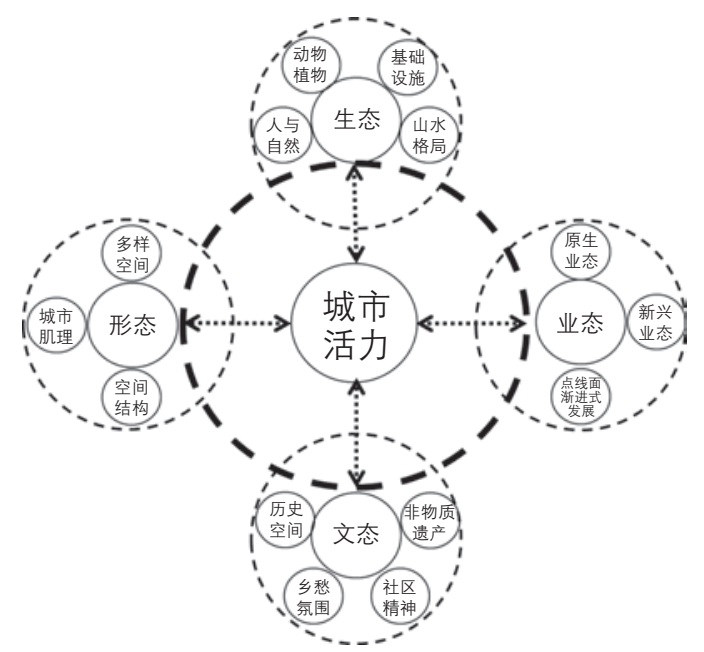

图 4 城市活力的组成要素及其关系

资料来源：作者绘制

\section{表 6 活化存量土地中政府的主要权责}

\begin{tabular}{|c|c|c|c|c|}
\hline 组织层面 & 政策层面 & 经济层面 & 人才层面 & 宣传层面 \\
\hline $\begin{array}{l}1 \text { 发挥组织优势, 确立强有力的领导 } \\
\text { 团队; } \\
2 \text { 通过法规或行政命令, 从制度层面 } \\
\text { 对居委会或其他领导团队的权限与职 } \\
\text { 责做出明确规定 ; } \\
3 \text { 明确非政府组织参与的责任与权利 }\end{array}$ & $\begin{array}{l}1 \text { 发挥政府导向作用, 提出存量土地发 } \\
\text { 展总体规划, 明确发展方向与方式; } \\
2 \text { 划分片区, 有计划的依序启动, 科学 } \\
\text { 再利用存量土地 ; } \\
3 \text { 通过立法等明确界定居民正式参与的 } \\
\text { 规范与流程 }\end{array}$ & $\begin{array}{l}1 \text { 评估存量土地价值, 设定不同 } \\
\text { 类型土地的收人方式, 增加投 } \\
\text { 资效益; } \\
2 \text { 总体引导, 减少大规模改造的 } \\
\text { 费用; } \\
3 \text { 合理规划业态, 指引经济走向 }\end{array}$ & $\begin{array}{l}1 \text { 培训社区规划师, 助 } \\
\text { 力社区发展 }{ }^{1} \text {; } \\
2 \text { 鼓励社会热心人士. } \\
\text { 非政府组织、大学生团 } \\
\text { 体等深人社区, 提供服 } \\
\text { 务, 充实社区人力资源 }\end{array}$ & $\begin{array}{l}1 \text { 利用媒体传播优势, } \\
\text { 形成全社会关注存量 } \\
\text { 土地的氛围 ; } \\
2 \text { 推广成功的社区或项 } \\
\text { 目经验 }\end{array}$ \\
\hline
\end{tabular}

资料来源 : 作者绘制

(1) 厦门市思明区的社区规划师培训课程, 面向两类人群: 一类是社区工作者、专业社工; 另一类则是社区里有特长的热心居民。参见厦门市思明 区政府网站 http://www.siming.gov.cn/xxgk/xwgg/jrsm/201505/t20150511_76737.htm。 
通渔村, 后来艺术家人住提升了社区声誉与艺术氛围, 再成立 业主协会、文创会等自治组织, 制订《曾厝垵文创村自治公约》, 共管共治, 带动旅游业态迅速发展, 终于发展成为 “中国最美 的渔村”。形态上, 它保留了具有闽南风格的红砖古厝、南洋 风格的 “番仔楼”, 并整理了破损严重的建筑, 改善了脏乱差 的街角空间; 生态上,充分利用依山傍海的优势, 提出 “不填塘、 慎砍树” 的原则, 确立面朝大海的渔村景致; 业态上, 鼓励产 品与服务创新, 发展特色民宿、文创产品, 仅 2014 年就吸引 游客 1000 余万人次, 成为文艺青年的集聚地 ; 文化方面延续 地方独特传统, 保留天妈宫、曾氏祖祠等信仰, 并在妈祖诞辰 等传统节日期间邀请闽南芕剧和歌仔剧等传统戏剧团体演出。

\section{3 奖补并重一一活化存量土地的落地策略}

资源配置的优化应避免现行体制中重实体、轻程序的缺 陷。“奖补并重”采用普遍性补助与差异化奖励相结合的方 式，给予居民自主修缮资金支持与宣传引导（图 5)。在总 体规划引导下, 按比例补助, 为修缮提供启动资金。奖励制 度采用项目竞争机制, 资金奖励竞赛胜出者。

作为制度设计的落地策略, 补助制度针对后进对象, 堵 住改造中的短板, 体现公平与关怀。奖励激发竞争, 竞争促 进合作, 能充分调动居民参与的积极性与责任感, 使参与者 关系更为密切, 带动居民共同关注城乡发展 (表 8 )。奖励 当然不是目的, 补贴也不是可持续之道, 需要两者相结合, 启动存量土地活化项目, 促进各阶层公平参与, 发挥生活空 间权益保障机制的作用, 才能建立地域活化良性互动的长效 参与机制。

\section{5 结语}

从粗放的、不可持续的大拆大建, 到历史建筑的拆、改、

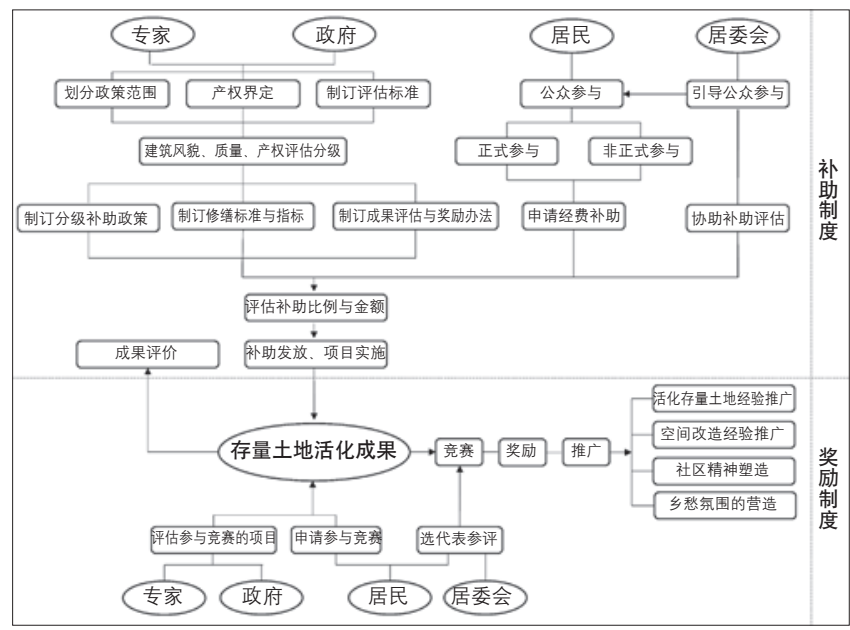

图 5 “奖补并重” 模式 资料来源 : 作者绘制
留、修 (包括修旧如旧、仿古一条街等), 再到基于社区营 造理念的活力机制创新, 无论哪种途径, 都应首先着眼于作 为主体的人, 他们既是存量土地活化的推动者与受益者, 也 是存量土地发展之本。城市历史与文化的传承不能单靠物化 空间的改善, 更需要以人为载体, 实现城乡社区空间精神的 归属与弘扬。

台湾社区营造成功经验之精要归结为 : 重视人的主体性 地位; 促进不同推动主体在社区精神凝聚下的互动, 以营造 项目为抓手, 形成社区营造机制; 社区自主运作与外界力量 的共同参与, 活化社会氛围, 进而推动存量土地活化。

结合台湾经验与大陆自身优势, 补足存量规划中居民、 社会参与不足的短板, 活化存量土地可以考虑以下有效途 径：（1）发挥组织优势, 界定好各方的权利与义务, 构建更 为高效的体制与机制; (2) 通过政策、资金、人才、宣传等 多方面的导向与支持, 在超越社区的更大社会范围里形成共 识, 凝聚愿景 ; (3) 发挥历史文化底蕴优势, 深人挖掘城乡 空间内涵, 共同营造 “乡愁” 氛围, 激发城乡空间新活力; （4）加强制度创新, 构建 “活力设计” “奖补并重” 等活 化模式, 实现存量土地经济价值、社会价值、环境价值的 共同提升。Ⓟ

\section{表 7 激发城市活力的途径与方法}

\begin{tabular}{|c|c|}
\hline E态 & $\begin{array}{l}1 \text { 升级各类基础服务设施, 生活环境现代化; } \\
2 \text { 保护、利用山水格局、动植物等地方资源要素; } \\
3 \text { 研拟人口迁出与保留比例, 合理划定土地承载力, 确保城市生态安全 }\end{array}$ \\
\hline & $\begin{array}{l}\text { 间，避免形态的剧变引起居民不适应； } \\
\text { 烓巷院等空间特色, 以及历史风貌建筑的地方特征; } \\
\text { 共交往空间 }\end{array}$ \\
\hline & $\begin{array}{l}1 \text { 培育原生种子, 扶持本地老字号等特色产业, 鼓励传统业态升级; } \\
2 \text { 植人新兴种子, 导人新的业态, 如体验式店铺、街角博物馆; } \\
3 \text { 以业态种子为核心, 促进 “点一线一面” 渐进式发展 }\end{array}$ \\
\hline 又心 & $\begin{array}{l}1 \text { 整体保护有价值的城乡空间, 多种手段更新历史建筑, 营造时代乡愁 } \\
\text { 氛围; } \\
2 \text { 编制、弘扬非物质文化遗产, 实现传统文化与精神的当代传承; } \\
3 \text { 挖掘潜在文化价值, 梳理城乡历史脉络; } \\
4 \text { 开展文化活动, 增强市民的参与感, 凝聚社区精神 }\end{array}$ \\
\hline
\end{tabular}

资料来源 : 作者绘制

表 8 奖、补策略对比

\begin{tabular}{|c|c|c|c|c|}
\hline 资助类型 & 操作方式 & 优点 & 不足 & 适用情况 \\
\hline $\begin{array}{l}\text { 补助 } \\
\text { ( 输 血 功 } \\
\text { 能) }\end{array}$ & $\begin{array}{l}1 \text { 申请 } 2 \text { 评估 } \\
3 \text { 发放 } 4 \text { 评价 } \\
\text { (最终过渡到奖 } \\
\text { 励) }\end{array}$ & $\begin{array}{l}\text { 公平、简单； } \\
\text { 涉及面广、受益人数多; } \\
\text { 为自主修缮提供基本经费 }\end{array}$ & $\begin{array}{l}\text { 资助额 度有 } \\
\text { 限, 针对性不 } \\
\text { 强, 鼓励惰性 }\end{array}$ & $\begin{array}{l}\text { 初期启动, } \\
\text { 贫困人口 }\end{array}$ \\
\hline $\begin{array}{l}\text { 奖励 } \\
\text { （造血机 } \\
\text { 制） }\end{array}$ & $\begin{array}{l}1 \text { 申请 } 2 \text { 竞赛 } \\
3 \text { 奖励 } 4 \text { 推广 }\end{array}$ & $\begin{array}{l}\text { 对象明确、鼓励性强; } \\
\text { 利于宣传; } \\
\text { 政府有效导向 }\end{array}$ & $\begin{array}{l}\text { 容易“锦上 } \\
\text { 添花”, 不易 } \\
\text { “雪中送炭” }\end{array}$ & $\begin{array}{l}\text { 竞赛胜出 } \\
\text { 者 }\end{array}$ \\
\hline
\end{tabular}

资料来源 : 作者绘制 


\section{参考文献}

[1] 郭湘闽. 论上地发展权视角下旧城保护与复兴规划一以北京为例 [J]. 城市规划, 2007(12): 66-72.

[2] 姚存卓. 浅析规划管理部门在存量土地管理中存在的问题与解决途径 [J]. 规划师, 2009(10): 81-84.

[3] 刘宣。旧城更新中的规划制度设计与个体产权定义一一新加坡牛车水 与广州金花街改造对比研究 [J]. 城市规划, 2009(8): 18-25.

[4] 邹兵. 行动规划 - 制度设计・政策支持——深圳近 10 年城市规划实 施历程剖析 [J]. 城市规划学刊, 2013(1): 61-68.

[5] 何芳, 张皓. 我国城市存量土地盘活政策创新实践及启示 [J]. 改革与战 略, 2013(12): 21-24.

[6] 冯长春, 程龙, 老城区存量土地集约利用潜力评价—以北京市东城 区为例 [J]. 城市发展研究, 2010(7): 86-92.

[7]王嘉, 郭立德. 总量约束条件下城市更新项目空间增量分配方法探 析一以深圳市华强北地区城市更新实践为例 [J]. 城市规划学刊, 2010(7): 22-29

[8] 杨俊宴, 史宜. 老城中心区的发展演替及动力机制研究—以上海市 中心人民广场地区为例 [J]. 城市规划学刊, 2014(2): 51-59.

[9]冯立, 唐子来。产权制度视角下的划拨工业用地更新: 以上海市虹口 区为例 [J]. 城市规划学刊, 2013(5): 23-29.

[10] 孙施文, 周宇.上海田子坊地区更新机制研究 [J]. 城市规划学刊, 2015(1): 39-45.

[11] 周俭, 陈亚斌. 类型学思路在历史街区保护与更新中的运用一以上海 老城厢方洪中路街区城市设计为例 [J]. 城市规划学刊, 2007(1): 61-65.

[12] 何依, 邓巍. 历史街区建筑肌理的原型与类型研究 [J]. 城市规划, 2014(8): 57-62.

[13] 童明. 城市肌理如何激发城市活力 [J]. 城市规划学刊, 2014(3): 85-96.

[14] 周向频, 唐静云. 历史街区的商业开发模式及其规划方法研究——以成 都锦里、文殊坊、宽窄巷子为例 [J]. 城市规划学刊, 2009(8): 107-113.

[15] 李和平, 薛威. 历史街区商业化动力机制分析及规划引导 [J]. 城市规划 学刊, 2012(4): 105-112.

[16] 赵民. “社区营造”与城市规划的“社区指向”研究 [J]. 规划师, 2013(9): 5-10.

[17] 丁康乐, 黄丽玲, 郑卫. 台湾地区社区营造探析 [J]. 浙江大学学报( 理 学版), 2013(6): 716-725.

[18] 杨芙蓉, 黄应霖. 我国台湾地区社区规划师制度的形成与发展历程探 究 [J]. 规划师, 2013(9): 31-35.

[19] 邹兵. 增量规划、存量规划与政策规划 [J]. 城市规划, 2013(2): 35-37.

[20] 陈宏胜, 王兴平, 国子健规划的流变——对增量规划、存量规划、减 量规划的思考 [J]. 现代城市研究, 2015(9): 44-48.

[21] 邹兵.由 “增量扩张”转向 “存量优化” ——深圳市城市总体规划转 型的动因与路径 [J]. 规划师, 2013(5): 5-10.

[22] 赵燕菁. 存量规划: 理论与实践 [J]. 北京规划建设, 2014(4): 153-156.

[23] 黄世辉. 社区自主营造的理念与机制一一黄世辉研究论文集 [M]. 台北: 建筑情报季刊杂志社, 2001 .

[24] Arnstein S R. A Ladder of Citizen Participation [J]. Journal of the American Institute of Planners, 1969(35): 216-224.

[25] 张庭伟。中国规划改革面临倒逼: 城市发展制度创新的五个机制 [J]. 城 市规划学刊, 2014(5): 7-14.

[26] 初松峰, 孙振义. 项目导向下的台湾社区营造关键因素分析 [C]//台 湾地区都市计划学会. 2014 年都市计划年会论文集, 2014.

[27] 邹萍萍.社区营造与地方探讨一以新竹市金山社区与内湖社区为例 [D]. 台北: 台湾师范大学硕士学位论文, 2008 .

[28] Coase R H. The Federal Communications Commission[J]. Journal of Law and Economics, 1959 (2): 1-40.

[29] 张五常. 经济解释卷四: 制度的选择 [M] . 北京: 中信出版社, 2014.

[30] 林一琳, 县花一现的在地社区营造? 一一斗六市龙潭社区社造之行动 研究 [D]. 云林: 云林科技大学硕士学位论文, 2011.

[31] “台湾地区行政机构文化建设委员会”. 文化替代役简介 $[\mathrm{M}]$. 台北市: “台湾地区行政机构文化建设委员会”编印, 1994.

[32] 黄䞏雅, 社区营造与社区的永续发展——鹿野乡永安社区为例 [D].
台东: 台东大学硕士学位论文, 2010 .

[33] 萧江碧，孙振义。低碳社区推动专案工作计划(第一年). 台北：“行政 院环境保护署”专案计划, 2011.

[34] 杨继祥, 林岑。海沧社区大学“升级版”覆盖全区 [N]. 厦门日报, 2015-06-19

[35] 郝程. 互动共治: 外来居民对当地事务的参与一一基于海沧兴旺社区 新厦门人综合体的研究 [D]. 武汉: 华中师范大学硕士学位论文, 2015.

(本文编辑：许玫)

附录：台湾地区社区营造案例部分资料汇总

序号数据来源

1 黄世辉. 社区自主营造的理念与机制一一黄世辉研究论文集 [M]. 台北: 建筑情报季刊杂志社, 2001 .

2 刘建志. 台湾农村社区营造之研究- 以台中石冈龙兴里为例 [D]. 台中: 朝阳科技大学硕士学位论文, 2010

3 赖怡吟. 屏东县新埤乡建功社区的聚落拓剭与社区营造历程 [D]. 高雄 : 高雄师范大学硕士学位论文, 2006 .

4 刍萍萍. 社区营造与地方探讨一一新竹市金山社区与内湖社区为例 [D]. 台北 : 台湾师范大学硕士学位论文, 2008

5 杨司焕. 台东县鹿野乡永安社区营造模式之探讨 [D]. 台南 : 嘉南药理科 技大学硕士学位论文, 2013 .

6 黄䞏雅. 社区营造与社区的永续发展一一鹿野乡永安社区为例 [D]. 台 东: 台东大学硕士学位论文, 2010 .

7 吴志文. 建功社区林域空间拓殖计划一一屏东县新埤乡客家聚落社区营 造纪实 [D]. 台南 : 台南艺术学院硕士论文, 2004.

8 吕嘉泓. 社区营造在永续发展中之角色一一嘉义县山美社区为例 [D]. 嘉义: 中正大学硕士学位论文, 1999.

9 郭士杰. 由社区营造实现公民社会: 以新北市平潭社区为例 [D]. 台北 : 台北市立教育大学硕士学位论文, 2011 .

10 黄郁胜. 合作社参与社区营造之研究一以白米、泰山社区合作社為例 [D]. 台北: 台北大学硕士学位论文, 2008.

11 郑和. 乡村型社区营造之网络治理策略——南投县国姓乡梅林社区个案 研究 [D]. 南投 : 暨南国际大学硕士学位论文, 2009.

12 王万此. 社区营造的研究与批判一以溪美社区為例 [D]. 嘉义: 南华大 学硕士学位论文, 2006 .

13 邱于珊. 花莲县牛犁社区交流协会推动寿丰乡安全社区营造之研究 [D]. 花莲 : 东华大学硕士学位论文, 2010 .

14 扈凯晖. 民众参与社区营造及居住环境感受之研究——以嘉义市刘昔社 区為例 [D]. 嘉义: 嘉义大学硕士学位论文, 2007.

15 陈名扬. 社区发展协会在社区营造中的角色与功能一一嘉义县明华社 区发展协会為例 [D]. 嘉义: 南华大学硕士学位论文, 2013 .

16 周玉堡. 非营利组织推动客家社区营造之研究——以东势庄文化协会为 例 [D]. 桃园 : 中央大学硕士学位论文, 2011.

17 杨桂珍. 社会资本与社区营造: 以湖口乡信势社区为个案研究 [D]. 新竹: 交通大学硕士学位论文, 2008 .

18 张志伟. 金门新前墩聚落的社区营造 [D]. 金门: 金门大学硕士学位论文, 2011. 